\title{
Öğretmen Adaylarının Bilgi Okuryazarlı Becerileri İle Bilgi Kaynaklarının Güvenilirliklerini Değerlendirmeleri Arasındaki İlişki *
}

\section{The Relation between the Information Literacy Skills of Pre-Service Teachers and Their Evaluation of the Trustworthiness of Information Sources}

\author{
Canan Dilek Eren a,**, Gülfem Muşlu Kaygısız ${ }^{\mathrm{b}}$, Elif Benzer ${ }^{\mathrm{c}}$

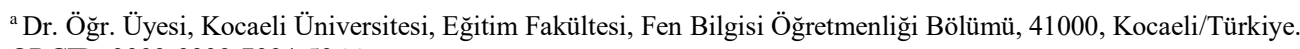 \\ ORCID: 0000-0002-7004-5066
}

b Dr. Öğr. Üyesi, Hasan Kalyoncu Üniversitesi, Eğitim Fakültesi, Sınıf Öğretmenliği Bölümü, 27000, Gaziantep/Türkiye. ORCID: 0000-0003-3286-0454

${ }^{c}$ Doç. Dr., Marmara Üniversitesi, Atatürk Eğitim Fakültesi, Fen Bilgisi Öğretmenliği, 34722, İstanbul/Türkiye.

ORCID: 0000-0002-2518-7681

\section{MAKALE BILGİSI}

\section{Makale Geçmişi:}

Başvuru tarihi: 02 Nisan 2018

Düzeltme tarihi: 22 Haziran 2018

Kabul tarihi: 17 Temmuz 2018

\section{Anahtar Kelimeler:}

Bilgi Okuryazarlık Becerileri

Bilgi Kaynaklarına Olan Güven

Sosyobilimsel Konular

Nükleer Enerji

Öğretmen Adayı

\section{ARTICLE INFO}

\section{Article history:}

Received April 2, 2018

Received in revised form June 22, 2018

Accepted July 17, 2018

\section{Keywords:}

Information Literacy Levels

Trustworthiness on Information Sources

Socioscientific Subjects

Nuclear Energy

Pre-Service Teachers
ÖZ

Bu çalışmanın amacı, fen bilgisi öğretmen adaylarının bilgi okuryazarlık becerileri ile sosyobilimsel bir konu olan nükleer enerji hakkında çevrimiçi farklı bilgi kaynaklarından alınan metinlerin güvenilirliklerini değerlendirmeleri arasında bir ilişki olup olmadığını incelemektir. Araştırma ilişkisel tarama modelindedir. Çalışma Kocaeli Üniversitesi'nde fen bilgisi öğretmenliği programındaki 186 öğretmen adayıyla yürütülmüştür. Çalışmada veriler "bilgi okuryazarlığı ölçeği" ve "güvenirlik anketi” ile toplanmıştır. Katılımcılar önce nükleer enerji konusunda özgün ve farklı bilgi kaynaklarından derlenmiş olan okuma metinlerini incelemiş, sonrasında bilgi okuryazarlığı ölçeğini ve her bir metin için güvenirlik anketini doldurmuşlardır. Bulguların değerlendirilmesi sonucunda fen bilgisi öğretmen adaylarının, bilgi okuryazarlığı konusunda yüksek beceri düzeyine sahip oldukları ve bilgi okuryazarlık beceri düzeyleriyle çevrimiçi farklı bilgi kaynaklarının güvenilirliklerini değerlendirmeleri arasında düşük düzeyde ve pozitif yönde bir ilişkinin olduğu belirlenmiştir.

\section{A B S T R A C T}

The aim of this study is to examine whether there is a relation between the information literacy skills of pre-service science teachers and their evaluation of the trustworthiness of texts obtained from different online information sources about nuclear energy, which is a socioscientific subject. The study is in relational screening model. The study was carried out by 186 pre-service teachers getting education at science teaching program at Kocaeli University. In the study, data were collected through "Information literacy scale" and "Trustworthiness questionnaire". Participants first looked at reading texts compiled from original and different sources of information about nuclear energy, then filled the Information Literacy Scale and the Trustworthiness Questionnaire for each text. Findings show that pre-service science teachers have high skill level in information literacy subject and there is a low level and positively relation between their information literacy skill levels and their evaluation of the trustworthiness of online different information sources.

\footnotetext{
* Bu çalışma 28 Nisan - 1 Mayıs tarihleri arasında Marmaris’te düzenlenen Uluslararası Matematik, Fen ve Teknoloji Eğitimi ( International Conference on Education in Mathematics, Science and Technology, ICEMST) Konferansi'nda bildiri olarak sunulmuştur

** Sorumlu yazar/Corresponding author.

e-posta: canandilek@gmail.com
} 


\section{Giriş}

Taşın neden oluştuğunu bilmeden, avını yonttuğu taşla daha kolay avlayan, kimyasal bileşimini bilmeden içinde yiyeceğini pişirip saklayabileceği kapları yapan, inşası için gerekli tekniğini bilmeden yırtıcı hayvanlardan korunacağı barınağını yapan, suyun kaldırma kuvvetini bilmeden nehrin öbür yakasına geçebileceği salını yapan ilk insan için bilgi kaynağı; içinde bulunduğu doğada yaptığı gözlemlerdi. Doğayı gözlemle başlayıp günümüzde halen devam etmekte olan ve Yörükoğulları, Orhun, Topdemir ve İhsanoğlu'na (2013) göre bilimsel ve teknolojik araştırma olarak da adlandırabileceğimiz icat ve keşif faaliyetleri, ulusların kendi toplumlarının refah seviyesini yükseltmek için gösterdikleri gayretle, 21.yüzyılın eşiğinde insanlığın bilgi çağına girmesine neden olmuştur.

Bilgi çağı, bilginin dijital formlar halinde kaydedildiği (Lemke ve Brenner, 2015), insandaki organik sinir sistemine benzetilebilir dijital ağlarla yayılımının gerçekleştiği (Bozkurt, 2014), bilgilenmenin ve sürekli öğrenmenin kaçınılmaz olduğu, çalışanlarının çoğunun bilgi çalışanlarından oluştuğu yeni toplumsal ve ekonomik dönemdir (Bedük ve Balcılar, 2008). Bu çağın oluşumuna yol açan teknolojiler; bilgisayar, mikro-elektronik, robot ve kontrol, iletişim, bio-teknoloji, malzeme ve enerji teknolojileri (Akolaş, 2004) ile bilişim sistem ve teknolojilerindeki gelişmelerdir. Bilişim sistem ve teknolojilerindeki gelişmeler, zamandan ve mekândan bağımsız bir şekilde bilginin erişilebilirliğini, kaydedilebilirliğini, depolanabilirliğini sağlarken bilginin ivmelenerek artması bireyin kendisine gerekenden daha fazla bilgiye maruz kalmasına neden olmuştur. 1962'ye gelindiğinde ekonomist Fritz Machlup tarafindan ilk kez bilginin yarı-ömrü kavramı tanımlanmıştır. Bu kavram, bilgiye erişildiğinde bilginin çoktan doğru ve güncel kabul edilecek ömrünün yarısına ulaşmış olacağı anlamına gelmektedir (Murugesan, 2014). İvmelenerek artan bilgi ve onun bir sonucu olan bilginin yarı-ömrü gerçeği bu çağda bilgiye erişebilmenin ötesinde, bilgiyi filtreleyebilme ve bilgiyi amaca uygun bir şekilde kullanabilme becerilerinin de gerekliliğini zorunlu hale getirmiştir. Bilgi okuryazarlığ da bu becerilerinden biridir.

Bilgi okuryazarlığı ülkeden ülkeye, kültürden kültüre ve hatta dilden dile 'bilgi yetkinliği', 'bilgi akıcılığı' gibi türetilmiş olan birçok kavramla adlandırılmıştır (Horton, 2008); ancak kapsamının genişliği, kavramın kendisinden ya da eş anlamlısı diyebileceğimiz alternatif kavramlarından daha çok içeriğinin ve bireylere kazandıracağı yetkinliklerin açıklığa kavuşturulmasını daha anlamlı kılmaktadır. Kasım 2005 'de, İskenderiye'de, 'Bilgi Toplumunun Fenerleri' başlığı altında yapılan bilgi okuryazarlığı ve yaşam boyu öğrenmenin konu edildiği uluslararası bir toplantıda bilgi okuryazarlığı kavramı kapsamlı bir şekilde tanımlanmış ve sonuç bildirgesinde de bu tanıma yer verilmiştir. Alexandria Proclamation'ne (İskenderiye Bildirgesi) (2005) göre, bilgi okuryazarlığı; bireylerin kişisel, sosyal, mesleki ve eğitimlerine ilişkin hedeflerini gerçekleştirebilmeleri için etkili bir şekilde bilgi arama, değerlendirme, kullanma ve bilgiyi oluşturma süreçlerinde yetkilendirilmesi anlamına gelir ve dijital dünyada temel bir insanlık hakkıdır.
Bilgi okuryazarlığı yetkinlikleri söz konusu olduğunda literatürde dünyanın en eski ve en büyük kütüphaneciler derneği olan Amerikan Kütüphaneciler Derneği (ALA) tarafından 2000 yılında yükseköğretim için belirlenmiş olan bilgi okuryazarlığı yetkinlik standartlarına değinildiği görülmektedir. ACRL'ye (Association of College and Research Libraries \& American Library Association) (2000) göre, bilgi okuryazarı bir bireyin şunları yapabiliyor olması gerekmektedir;

(i) Gereksinim duyduğu bilginin kapsamını belirleme

(ii) Gereksinim duyduğu bilgiye etkin ve etkili biçimde ulaşma

(iii) Bilgiyi ve bilgiye ilişkin kaynakları eleştirel bakış açısıyla değerlendirme

(iv) Ulaştığı bilgileri önceki bilgilerine dâhil etme

(v) Belirli bir amaca ulaşmak için bilgiyi etkili bir şekilde kullanma

(vi) Bilgi kullanımına ilişkin sosyal ve ekonomik haklarını bilme, bilgiye erişimde ve kullanımında etik ve yasal kurallara riayet etme.

Sayers'a (2006) göre 21. yüzyılın başlarında bilgiye dair ön plana çıkacak en önemli kaygıların; aşırı bilgi yüklenmesi, eşit olmayan bilgi dağılımı, önemsiz bilgiye yönelik yoğun bir eğilim ve bilginin güvenilirliği olacağı yönündedir. $\mathrm{Bu}$ durumda, son yıllarda parabolik olarak üretilen ve hızla tüketilen bilgiye erişimde, değerlendirilmesinde ve kullanımında bireylerin bilgi okuryazarı olmaları önemlidir. Bununla birlikte, ACRL'nin (2000) belirlemiş olduğu bilgi okuryazarı bir bireyin sahip olması gereken standartların yanı sıra, bir de bireylerin ulaştıkları bilginin, bilinçli bir şekilde güvenilirliğini belirleyebilmeleri de gereklilik arz edecektir.

Dünyanın ilk bilgi işlem ağı, Soğuk Savaş döneminde, bilim insanlarının ve araştırmacıların birbirleri ile dosya paylaşımında bulunmalarını sağlamak, aralarındaki işbirliğini kolaylaştırmak, nükleer bir saldırıda telefon hatları kullanılamaz olduğunda bilgisayar iletişiminin sürdürülmesini sağlamak amaciyla kurulmuş olan Arpanet (Advanced Research Projects Agency Network) tir. Arpanet'in (Amerikan Gelişmiş Savunma Araştırmaları Dairesi Ağı) sınırlayıcı yanı o yıllarda herkese açık olmamasıdır. 90'lı yıllara gelindiğinde Arpanet geliştirilerek yerine kapalı bir ağ yapısına sahip olmayan internet kullanılmaya başlanmıştır. Askerî amaçlarla kurulmuş olan internet altyapısına, insanların gündelik yaşantısına dâhil olarak yaygın kullanıma açılması için, World Wide Web (www) başta olmak üzere birçok modern internet aracı eklenmiştir (Değirmencioğlu, 2016). Her ne kadar kaç tanesinin aktif olduğu bilinmese de 2000 yılında 7 milyon civarında olan web sitesi sayıs1, 2005'te 46,5 milyona çıkarken (Dobrow, 2013), bu sayının 5 Ocak 2015'te 45,5 milyar olduğu görülmüştür (Van den Bosch, Bogers ve De Kunder, 2016). Bilgiye ulaşımın kolaylaşmış olması, sunulan bilgilerin hacmi ve çeşitliliği başta araştırmacılar ve öğrenciler olmak üzere birçok kişi için bilgiye erişimde web sitelerini önemli ve vazgeçilmez bir kaynak durumuna getirmiştir. Ancak web üzerinden yayınlanan bilgi sayfaları için denetim mekanizması söz konusu olmadığından, bilginin güvenilirliği sorunu ortaya çıkmaktadır. 
Demokratik toplumlarda, bireylerin toplumsal konularla ilgili verecekleri kararların niteliği çok önemlidir (Kolstø, 2001). Nitelikli karar verebilmeleri ise çoğunlukla tartışmaya açık ve açık uçlu olarak tanımlayabileceğimiz sosyobilimsel konularda görüş sahibi olmalarına ve bu konularda ilgili ve dikkatli davranmalarına bağlıdır. Sosyobilimsel konular, fen eğitiminin önemli bir parçasıdır ve gelecek nesilleri yetiştirecek olan fen bilgisi öğretmen adaylarının da sosyobilimsel konulara ilişkin karar verme sürecinde bilgi okuryazarı olmaları ve bilgi kaynaklarının güvenilirliklerini değerlendirme konusunda yetkinlik kazanmış olmaları gerekmektedir. Literatürde, bilgi okuryazarlığı ile ilgili olarak, bilgi okuryazarlık becerisinin, öğrenmeye ilişkin tutum (Adıgüzel, 2014), bilimsel araştırmaya yönelik tutum (Dombaycı ve Ercan, 2017) ve sanal zorbalık (Demir ve Seferoğlu, 2016) ile ilişkisinin araştırıldığı çalışmalar yer almaktadır. Sosyobilimsel bir konu olan iklim değişikliği konusunda, üniversite öğrencilerinin, çoklu bilgi kaynaklarına olan güvenirliklerinin (Bråten, Strømsø ve Salmerón, 2011), iklim değişikliği, nükleer enerji, organ bağışı ve nakli hakkında, öğretmen adaylarının, bilgi düzeylerinin, epistemolojik inançlarının ve farklı kaynakların güvenirliklerini değerlendirmeleri arasındaki ilişkinin (Saylan, 2014) araştırıldı̆̆ çalışmalar da yer almaktadır. Ancak öğretmen adaylarının bilgi okuryazarlık beceri düzeyleri ile çevrimiçi bilgi kaynaklarına olan güvenilirlikleri ve bu ikisi arasındaki ilişkinin belirlenmeye çalışıldığı araştırmaya rastlanmamıştır. Fen bilgisi öğretmen adaylarının, bilgi okuryazarlık becerilerinin, sosyobilimsel bir konu olan nükleer enerji santralleri hakkında farklı bilgi kaynaklarından alınan metinlerin güvenilirliklerini nasıl değerlendirdiklerinin; güvenilirlik kriterlerinin neler olduğunun; fen bilgisi öğretmen adaylarının bilgi okuryazarlık becerileri ile farklı bilgi kaynaklarının güvenilirliklerini değerlendirmeleri arasında bir ilişki olup olmadığının incelenmesi, öğretmen adaylarının yetkinliklerinin ya da eksikliklerinin farkına varılmasını sağlayacak olması ve alanda yapılacak çalışmalara katkı sağlayacak olması nedeniyle önemlidir.

$\mathrm{Bu}$ araştırmada, fen bilgisi öğretmen adaylarının, bilgi okuryazarlık becerilerinin, sosyobilimsel bir konu olan nükleer enerji hakkında farklı bilgi kaynaklarından alınan metinlerin güvenilirliklerini nasıl değerlendirdiklerinin; güvenilirlik kriterlerinin neler olduğunun, fen bilgisi öğretmen adaylarının bilgi okuryazarlık becerileri ile farklı bilgi kaynaklarının güvenilirliklerini değerlendirmeleri arasında bir ilişki olup olmadığının incelenmesi amaçlanmıştır. $\mathrm{Bu}$ amaçla aşağıda yer alan alt problemlere cevap aranmıştır;

(i) Fen Bilgisi Öğretmen adaylarının bilgi okuryazarlık beceri düzeyleri nedir?

(ii) Fen Bilgisi Öğretmen adaylarının bilgi okuryazarlık beceri puanları arasında cinsiyetlerine ve sinıf düzeylerine göre anlamlı bir farklılık var mıdır?

(iii) Fen Bilgisi Öğretmen adayları, nükleer enerji konusunda verilen farklı bilgi kaynaklarına ne ölçüde güvenmektedirler?

(iv) Fen Bilgisi Öğretmen adaylarının, nükleer enerji konusunda farklı bilgi kaynaklarından alınan metinlerin güvenilirliklerini değerlendirmelerine ilişkin puanları arasında cinsiyetlerine ve sınıf düzeylerine göre anlamlı bir farklılık var mıdır?

(v) Fen Bilgisi Öğretmen adaylarının, nükleer enerji konusunda verilen farklı bilgi kaynaklarının metinlerine dayanarak belirledikleri güvenilirlik kriterleri nelerdir?

(vi) Fen Bilgisi Öğretmen adaylarının, nükleer enerji konusunda farklı bilgi kaynaklarından alınan metinlerin, güvenilirliklerini belirleme kriterlerine ilişkin puanları arasında cinsiyetlerine ve sınıf düzeylerine göre anlamlı bir farklılık var mıdır?

(vii) Fen Bilgisi Öğretmen adayları, nükleer enerji santralleri konusunda farklı bilgi kaynaklarından alınan metinlerin kavranmasını ne ölçüde zor bulmuşlardır?

(viii) Fen bilgisi öğretmen adaylarının bilgi okuryazarlık becerileri ile farklı kaynakların güvenilirliklerini değerlendirmeleri arasında anlamlı bir ilişki var midir?

\section{Yöntem}

\subsection{Araştırmanın Modeli}

$\mathrm{Bu}$ çalışma, tarama modellerinden "ilişkisel tarama model"'ine uygun olarak düzenlenmiştir. Karasar'a (2014) göre, "İlişkisel tarama modelleri, iki veya daha çok sayıdaki değişken arasında birlikte değişim varlığını ve/veya derecesini belirlemeyi amaçlayan araştırma modelleridir." $\mathrm{Bu}$ kapsamda, fen bilgisi öğretmen adaylarının bilgi okuryazarlık becerileri ile farklı bilgi kaynaklarının güvenilirliklerini değerlendirmeleri arasındaki ilişki incelenmiştir.

\section{2. Çalışma Grubu}

$\mathrm{Bu}$ araştırmanın çalışma grubunu, Kocaeli Üniversitesi (KOÜ) Eğitim Fakültesi Fen Bilgisi Öğretmenliği programında öğrenim gören toplam 186 öğretmen aday oluşturmaktadır. Öğretmen adaylarının 50'si (\%26.9) birinci sinıf, 57'si (\%30.6) ikinci sınıf, 34'ü (\%18.3) üçüncü sınıf, 45'i (\%24.2) dördüncü sınıf; 166's1 (\%89.2) k1z, 20'si (\%10.8) erkektir. Araştırmanın çalışma grubu seçkisiz olmayan (olasılıklı olmayan) örnekleme yöntemlerinden 'uygun örnekleme' (kolay bulunanı örnekleme) tekniğiyle oluşturulmuştur. Kolay bulunanı örnekleme yöntemi, yakın çevrede bulunan ve ulaşılması kolay olanın örnekleme alınmasıdır (Kılıç, 2013).

\subsection{Veri Toplama Araçları}

$\mathrm{Bu}$ araştırma kapsamında, üç adet veri toplama aracı kullanılmıştır. Ölçeklerin ilki "Bilgi Okuryazarlığı Ölçeği", ikincisi araştırmacı tarafından farklı bilgi kaynaklarından derlenen 4 Okuma Metni, üçüncüsü ise "Güvenilirlik Anketi' dir.

\subsubsection{Bilgi Okuryazarlı̆̆ı Ölçeği}

Fen Bilgisi Öğretmen adaylarının bilgi okuryazarlık beceri düzeylerini belirlemek için Adigüzel (2011) tarafindan geliştirilen "Bilgi Okuryazarlığ̀ Ölçeği” kullanılmıştır. Ölçek 29 madde ve 4 faktörden oluşmaktadır. Bu faktörler; "bilgi ihtiyacını tanımlama $(14,15,20,21,22,23,24$ ve 
28.maddeler), bilgiye erișme $(3,4,5,16,17,18,19,25,26,27$ ve 29 . maddeler), bilgiyi kullanma $(6,7,8,11$ ve 13 . maddeler) ve bilgiyi kullanmada etik ve yasal düzenlemeleri dikkate alma $(1,2,9,10$ ve 12. maddeler)"dir. 5'li likert tipinde olan ölçekteki, 1 seçeneği "hiçbir zaman", 5 seçeneği ise "her zaman" anlamına gelmektedir. Yetişkinler için geliştirilmiş olan ölçekten alınan puanın yüksekliği, kişilerin bilgi okuryazarlığı beceri düzeyinin de yüksekliğini göstermektedir. Ölçeğin bütününe ilişkin Cronbach Alfa güvenirlik katsayısı geliştirilmesi aşamasında 0.928 olarak belirlenmiştir. $\mathrm{Bu}$ araştırmada ise ölçeğin bütününe ilişkin 0.900; bilgi ihtiyacını tanımlama faktörü için 0.780 ; bilgiye erişme faktörü için 0,786; bilgiyi kullanma faktörü için 0,705 ve bilgiyi kullanmada etik ve yasal düzenlemeler faktörü için 0.678 olarak bulunmuştur (Adıgüzel, 2011).

\subsubsection{Okuma Metinleri}

Fen Bilgisi Öğretmen adaylarının bilgi kaynaklarına olan güvenlerini ve güvenilirlik kriterlerinin neler olduğunu belirlemek için araştırmacılar tarafından, sosyobilimsel bir konu olan nükleer enerji hakkında, eğitimli okuyucuların araştırmaları esnasında karşılarına çıkabilecek kaynakları temsil edecek şekilde seçilmiş, özgün, farklı bilgi kaynaklarından derlenmiş olan 4 okuma metni kullanılmıştır.

İlk metin, 314 kelimeden oluşmaktadır. 2013 yılında bir internet sitesinde yayınlanmış olan bir röportajdan alınmıştır. Röportaj yapılan akademisyen, profesör ünvanına sahip bir öğretim üyesi olmasının yanı sıra bir stratejik araştırmalar merkezinde de güvenlik ve nükleer enerji uzmanı olarak çalışmaktadır. Metinde, bazı çevrelerin gelişmekte olan ülkelerin nükleer enerji santrali kurma taleplerini gelişmiş ülkeler vazgeçmekte iddiaları ile göz ardı etmeye çalıştıklarını oysaki vazgeçtikleri için değil yeterli sayıda nükleer enerji santraline sahip oldukları için artık yenilerini kurma talebinde bulunmadiklarını, bunun yerine var olanların güvenliğini artırmak gibi daha önemli girişimlerde bulundukları belirtilmektedir. $\mathrm{Bu}$ çarpıtılmış iddialarla Türkiye'nin de nükleer enerji santrali kurmaktan vazgeçmesinin akılcı olmadığı savunulmaktadır.

243 kelimelik ikinci metin, Türkiye Atom Enerjisi Kurumunun, Nükleer Araştırma ve Eğitim Merkezi’nde görev yapan doktor unvanına sahip bir fizikçi tarafindan yazılmış, dergi yazısıdır. 2009 yılında bir internet sitesinde yayınlanmış olan yazıda, Çernobil'in kötü bir örnek olduğu ancak kötü örneğin emsal teşkil etmemesi gerektiği, Türkiye'nin nükleer enerji santralleri ile ilgili bilimsel ve teknolojik yetkinliğe, ekonomik ve siyasal bağımsızlığa ve demokrasiye sahip olduğu savunulmaktadır.

Üçüncü metinde 266 kelime yer almaktadır. 2017 yılında çevrimiçi bir gazetede yayınlanmış olan metin, gazetenin iklim ve enerji haberleri editörü ve aynı zamanda nükleer karşıtı bir web sitesinin de gönüllü proje koordinatörünün nükleer santrallerin tehlikelerine İlişkin görüşlerini içermektedir. Metinde, nükleer santrallerin ortaya çıkış sebebinin nükleer silahlar yani atom bombaları olduğu ve üretilmeye karar verilmesinin ise soğuk savaş yıllarına dayandığı, bugüne kadar yeterince kurulduğu ve birindeki patlamanın eşittir atom bombası olacağı, Sinop ve Mersin'deki nükleer enerji santrali projeleri ile ilgili çalışmaların devam etmekte olduğu, niyet silahlanma değilse yerli ve milli olan güneş ve rüzgâr enerjilerinin yeterli olacağı savunulmaktadır.

318 kelimeden oluşan dördüncü metin ise 2011 yılında bir internet sitesinde "Yaşamı Seçin Nükleerden Vazgeçin" adıyla online kitap olarak yayınlanmıştır. Profesör unvanına sahip bir öğretim üyesi olmasının yanı sıra sürdürülebilir yaşam ve ekoköyler konusunda çalışmalar yürütmekte olan bir akademisyenin görüşlerini içermektedir. Metinde, nükleer enerjiye evet denilmesi durumunda teknoloji ve yakıtı için dışa bağımlı olunacağı, Batı kızdırıldığında ülkemizi tehdit edecekleri, yakıtı dışında atıklarının giderilmesinin de masraflı olduğu, nükleer enerjinin, nükleer silah yapma isteğini de beraberinde getirip nükleer silah yapılmasa dahi, Irak'ta olduğu gibi, nükleer silahınız var diyerek birçok insanın ölümüne neden olunabileceği anlatılmaktadır.

Metinlerin her biri ayrı bir sayfada basılmıştır. Metindeki bilginin kaynağına ilişkin bilgiler yani yazarının adı, görev yaptığı kurumun ad1, kurumdaki görevi, varsa unvanı, dokümanın türü, yayın tarihi her bir metnin üst kısmına yazılmıştır.

\subsubsection{Güvenilirlik Anketi}

Fen Bilgisi Öğretmen adaylarının bilgi kaynaklarına olan güvenlerini ve güvenilirlik kriterlerinin neler olduğunu belirlemek için Bråten vd., (2011) tarafından geliştirilen ve Saylan (2014) tarafından Türkçe'ye uyarlanan, 10 lu likert tipindeki "Güvenilirlik anketi” uygulanmıştır. Bu anket üç kısımdan oluşmaktadır:

(i) Her bir metne olan güveni değerlendirmeye yönelik 'çok küçük bir ölçüde' (1) ile 'çok büyük bir ölçüde' (10) seçeneği arasında derecelendirilebilen 1 madde,

(ii) Her bir kritere olan güveni değerlendirmeye yönelik 'çok küçük bir ölçüde' (1) ile 'çok büyük bir ölçüde' (10) seçeneği arasında derecelendirilebilen 6 madde,

(iii) Her bir metnin anlaşılırlığını değerlendirmeye yönelik ‘çok kolay' (1) ile ‘çok zor' (10) seçeneği arasında derecelendirilebilen 1 maddedir.

Dört metin için toplamda 32 madde yer almaktadır. Saylan (2014) ölçeğin, Türkçe'ye uyarladığ 1 formunun Cronbach Alfa güvenirlik katsayısını 0.97 olarak belirlerken, bu çalışmada ise 0.87 olarak bulunmuştur.

\subsection{Verilerin Toplanmas1}

Çalışma grubunda yer alan her bir katılımcıya, dört metin rastgele sıralanmış olarak verilmiştir. Katılımcılar bu sırayı değiştirebilecekleri ve istedikleri sırayla okuyabilecekleri konusunda bilgilendirilmişlerdir. Katılımcılara kendilerine verilen metinleri okuduktan sonra, bu bilgilere dayanarak nükleer enerji santrallerinin yararları ve zararları ile Türkiye için nükleer enerji santrallerinin gerekli olup olmamasına ilişkin bir rapor yazacaklarını düşünerek okumaları yönünde bilgilendirme yapılmıştır. Böylelikle metinleri daha dikkatli ve eleştirel bir şekilde okumaları sağlanmaya çalışılmıştır. Ancak uygulamada katılımcılardan böyle bir rapor istenmemiştir. Tüm katılımcılar metinlerini okuyup araştırmacıya teslim ettikten sonra her birine, her bir metin için ayrı ayrı hazırlanmış olan metinlere ilişkin güvenilirlik anketleri ve bilgi okuryazarlığı ölçeğini içeren bir dosya verilmiştir. Zaman kullanımı konusunda katılımcılar 
sınırlandırılmamışlar ve cevaplama süreleri de kayıt altına alınmamıştır. Araştırmaya katılımda gönüllülük ve gizlilik esas alınmıştır.

\subsection{Verilerin Analizi}

Verilerin çözümlenmesinde SPSS 18.0 paket programı kullanılmıştır. Betimsel verileri raporlamak için ortalama ve standart sapmadan yararlanılmıştır. Bu süreçte anlamlılık düzeyi olarak 0.05 kabul edilmiştir. Kolmogrov-Smirnov Testi sonuçlarına göre verilerin normal dağılım gösterdiği ( $>$ >.05) belirlendiği için araştırmanın alt problemleri doğrultusunda, parametrik testlerden iki yönlü varyans analizi (ANOVA) ve pearson korelasyon katsayısı analiz teknikleri kullanılmıştır.

\section{Bulgular}

$\mathrm{Bu}$ bölümde, araştırmanın amacına yönelik verilen alt problemlere ilişkin bulgulara yer verilmiş ve tablolar halinde sunulmuştur.

3.1. "Fen Bilgisi Öğretmen adaylarının bilgi okuryazarlı beceri düzeyleri nedir?" Alt Problemine İlişkin Bulgular

Fen Bilgisi Öğretmen adaylarının bilgi okuryazarlık puanlarının dağılımını belirlemek için betimsel istatistik uygulanmıştır. Sonuçlar Tablo 1'de gösterilmektedir.

Tablo 1. Fen Bilgisi Öğretmen Adaylarının Bilgi Okuryazarlık Beceri Düzeylerinin Betimsel İstatistik Sonuçları

\begin{tabular}{lcc}
\hline Faktör & $\dot{\mathrm{X}}$ & $\mathrm{Sd}$ \\
\hline Bilgi İhtiyacını Tanımlama & 3,57 & 0,58 \\
Bilgiye Erişme & 3,73 & 0,54 \\
Bilgiyi Kullanma & 3,69 & 0,64 \\
Bilgiyi Kullanmada Etik ve Yasal & 3,87 & 0,60 \\
Düzenlemeleri Dikkate Alma & 3,70 & 0,48 \\
Toplam &
\end{tabular}

X̀ : 1.00-1.79 Hiçbir zaman, 1.80-2.59 Ara sıra, 2.60-3.39 Bazen, 3.40-4.19 Çoğu zaman, 4.20-5.00 Her zaman.

Tablo 1 incelendiğinde Bilgi Okuryazarlık Ölçeği için Fen Bilgisi Öğretmen adaylarının tüm faktörlerde ve toplam puana göre "çoğu zaman” düzeyinde görüşe sahip oldukları anlaşılmaktadır. Buna göre fen bilgisi öğretmen adaylarının, bilgi okuryazarlığı konusunda yüksek beceri düzeyine sahip oldukları söylenebilir.

3.2. "Fen Bilgisi Öğretmen adaylarının bilgi okuryazarlık beceri puanları arasinda cinsiyetlerine ve sinıf düzeylerine göre anlamlı bir farklllık var mıdır?" Alt Problemine İlişkin Bulgular

Fen Bilgisi Öğretmen adaylarının bilgi okuryazarlık puanlarının cinsiyetlerine ve sınıf düzeylerine göre anlamlı bir farklılık gösterip göstermediğini belirlemek için iki yönlü Anova testi yapılmıştır. Sonuçlar Tablo 2'de gösterilmektedir.

Tablo 2 incelendiğinde, cinsiyetin $(F=.500, p>.05)$ sınıfın $(\mathrm{F}=.347, \mathrm{p}>.05)$, fen bilgisi öğretmen adaylarının bilgi okuryazarlık beceri düzeyleri üzerindeki ayrı ayrı etkilerinin ve cinsiyet*sınıf ortak etkilerinin $(\mathrm{F}=.813, \mathrm{p}>.05)$ anlamsız olduğu bulunmuştur. Cinsiyet ve sınıf değişkenleri hem ayrı ayrı hem de birlikte fen bilgisi öğretmen adaylarının bilgi okuryazarlık beceri düzeylerini etkilememektedir.

Tablo 2. Fen Bilgisi Öğretmen Adaylarının Cinsiyet Ve Sınıf Düzeylerine Göre Bilgi Okuryazarlık Beceri Puanları Arasındaki Farklılığın Anlamlılığına İlişkin İki Yönlü Anova Sonuçları

\begin{tabular}{lccccc}
\hline Varyansın Kaynağı & $\begin{array}{c}\text { Kareler } \\
\text { Toplamı }\end{array}$ & sd & $\begin{array}{c}\text { Kareler } \\
\text { Ortalamas } 1\end{array}$ & $\mathrm{~F}$ & $\mathrm{p}$ \\
\hline Cinsiyet &, 116 & 1 &, 116 &, 500 &, 480 \\
Sinıf &, 242 & 3 &, 081 &, 347 &, 792 \\
Cinsiyet * Sinıf &, 568 & 3 &, 189 &, 813 &, 488 \\
Hata & 41,438 & 178 &, 233 & & \\
Toplam & 2601,598 & 186 & & & \\
\hline
\end{tabular}

3.3. “Fen Bilgisi Öğretmen adaylarl, nükleer enerji konusunda verilen farklı bilgi kaynaklarına ne ölçüde güvenmektedirler?" Alt Problemine İlişkin Bulgular

Fen Bilgisi Öğretmen adaylarının, nükleer enerji konusunda farklı bilgi kaynaklarından alınan metinlerin güvenilirliklerini değerlendirmelerine ilişkin verdikleri puanların dağılımını belirlemek için betimsel istatistik uygulanmıştır. Sonuçlar Tablo 3'de gösterilmektedir.

Tablo 3. Fen Bilgisi Öğretmen Adaylarının Çevrimiçi Bilgi Kaynaklarının Güvenilirliklerini Değerlendirmelerine İlişkin Betimsel İstatistik Sonuçları*

\begin{tabular}{clcc}
\hline Metin No & Konu/ Kaynak / Yayın Tarihi & $\dot{X}$ & sd \\
\hline 1 & Nükleer Enerji / Röportaj Yazısi/2013 & 6.12 & 2.07 \\
2 & Nükleer Enerji / Dergi Yazıs1/2009 & 5.59 & 2.34 \\
3 & Nükleer Enerji / Gazete Haberi/2017 & 6.27 & 2.33 \\
4 & Nükleer Enerji / Kitap/2011 & 6.38 & 2.34 \\
& Toplam & 6.09 & 1.42
\end{tabular}

*Ölçek, çok küçük bir ölçüde (1) ile çok büyük bir ölçüde (10) arasında derecelendirilmiştir.

Tablo 3' te, Fen Bilgisi Öğretmen adaylarının nükleer enerji santralleri ile ilgili çevrimiçi farklı bilgi kaynaklarından alınan metinlerin güvenilirliklerine ilişkin verdikleri puanların ortalamaları, standart sapma değerleri görülmektedir. Tablo 3 incelendiğinde, fen bilgisi öğretmen adaylarının nükleer enerji santralleri hakkında dergiden alınmış olan ikinci metni (5.59) daha az güvenilir bulurken, çevrimiçi kitaptan alınmış olan dördüncü metni (6.38) daha güvenilir bulmuşlardır. Ancak, çevrimiçi farklı bilgi kaynaklarından alınan metinlere ilişkin güvenilirlik puanları arasında anlamlı bir farklılık bulunmamaktadır.

3.4. “Fen Bilgisi Öğretmen adaylarının, nükleer enerji konusunda farkl bilgi kaynaklarından alınan metinlerin güvenilirliklerini değerlendirmelerine ilişkin puanlart arasında cinsiyetlerine ve sinıf düzeylerine göre anlamlı bir farklılık var midır?" Alt Problemine İlişkin Bulgular

Fen Bilgisi Öğretmen adaylarının, nükleer enerji konusunda farklı bilgi kaynaklarından alınan metinlerin güvenilirliklerini değerlendirmelerine ilişkin puanları arasında cinsiyetlerine ve sınıf düzeylerine göre anlamlı bir 
farklılık gösterip göstermediğini belirlemek için iki yönlü Anova testi yapılmıştır. Sonuçlar Tablo 4'de gösterilmektedir.

Tablo 4. Fen Bilgisi Öğretmen Adaylarının Cinsiyet Ve Sınıf Düzeylerine Göre Farklı Bilgi Kaynaklarından Alınan Metinlerin Güvenilirliklerini Değerlendirmelerine İlişkin Puanları Arasındaki Farklılığın Anlamlılığına İlişkin İki Yönlü Anova Sonuçları

\begin{tabular}{lccccc}
\hline $\begin{array}{l}\text { Varyansın } \\
\text { Kaynağ } 1\end{array}$ & $\begin{array}{c}\text { Kareler } \\
\text { Toplamı }\end{array}$ & sd & $\begin{array}{c}\text { Kareler } \\
\text { Ortalamas }\end{array}$ & F & p \\
\hline Cinsiyet & 3,524 & 1 & 3,524 & 1,785 & 0,183 \\
Sinıf & 9,45 & 3 & 3,15 & 1,596 & 0,192 \\
Cinsiyet * Sinıf & 5,086 & 3 & 1,695 & 0,859 & 0,464 \\
Hata & 351,336 & 178 & 1,974 & & \\
Toplam & 7286,813 & 186 & & & \\
\hline
\end{tabular}

Tablo 4 incelendiğinde, cinsiyetin $(F=1.785, \mathrm{p}>.05)$ ve sinıf düzeyinin $(\mathrm{F}=1.596, \mathrm{p}>.05)$, farklı bilgi kaynaklarından alınan metinlerin güvenilirliklerini değerlendirmelerine ilişkin puanları üzerindeki ayrı ayrı etkilerinin ve cinsiyet*sinıf ortak etkilerinin $(\mathrm{F}=.859, \mathrm{p}>.05)$ anlamsiz olduğu bulunmuştur. Cinsiyet ve sınıfın değişkenleri hem ayrı ayrı hem de birlikte fen bilgisi öğretmen adaylarının farklı bilgi kaynaklarından alınan metinlerin güvenilirliklerini değerlendirmelerine ilişkin puanlarını etkilememektedir.

3.5. "Fen Bilgisi Öğretmen adaylarının, nükleer enerji konusunda verilen farklı bilgi kaynaklarının metinlerine dayanarak belirledikleri güvenilirlik kriterleri nelerdir?" Alt Problemine İlişkin Bulgular

Fen Bilgisi Öğretmen adaylarının, nükleer enerji konusunda verilen farklı bilgi kaynaklarının metinlerine dayanarak belirledikleri güvenilirlik kriterlerine ilişkin verdikleri puanların dağılımını ortaya koymak için betimsel istatistik uygulanmıştır. Sonuçlar Tablo 5'de gösterilmektedir.

Tablo 5. Fen Bilgisi Öğretmen Adaylarının, Nükleer Enerji Konusunda Verilen Farklı Bilgi Kaynaklarının Metinlerine Dayanarak Belirledikleri Güvenilirlik Kriterlerine İlişkin Betimsel İstatistik Sonuçlar1*

\begin{tabular}{lcc}
\hline Faktör & $\dot{X}$ & Sd \\
\hline Yazarı & 5,90 & 2,72 \\
Yayıncısı & 5,14 & 2,57 \\
Türü & 5,48 & 2,27 \\
İçeriği & 7,82 & 1,78 \\
Okuyucunun Kendi Görüşü & 7,18 & 2,28 \\
Yayın Tarihi & 5,75 & 2,69 \\
Toplam & 6,21 & 1,56
\end{tabular}

*Ölçek, çok küçük bir ölçüde ( 1) ile çok büyük bir ölçüde (10) arasında derecelendirilmiştir.

Tablo 5' te, Fen Bilgisi Öğretmen adaylarının nükleer enerji santralleri ile ilgili çevrimiçi farklı bilgi kaynaklarından alınan metinlere dayanarak belirledikleri güvenilirlik kriterlerine ilişkin verdikleri puanların ortalamaları ve standart sapma değerleri görülmektedir. Tablo 5 incelendiğinde, fen bilgisi öğretmen adaylarının nükleer enerji santralleri hakkındaki metinlerin güvenilirlikleri hakkındaki kararlarını en çok metnin içeriği (7.82) ve kendi görüşleri (7.18) doğrultusunda verdikleri görülmektedir. Metinlerin yayıncılarını (5.14) ve metinlerin türünü ( 5.48) ise güvenilirlik hakkında karar vermede en az dikkate aldıkları da elde edilen diğer bir sonuçtur.

3.6. “Fen Bilgisi Öğretmen adaylarının, nükleer enerji santralleri konusunda farkl bilgi kaynaklarından alınan metinlerin, güvenilirliklerini belirleme kriterlerine ilişkin puanları arasinda cinsiyetlerine ve sinuf düzeylerine göre anlamlı bir farklılık var mıdır?" Alt Problemine İlişkin Bulgular

Fen Bilgisi Öğretmen adaylarının, nükleer enerji santralleri konusunda farklı bilgi kaynaklarından alınan metinlerin, güvenilirliklerini belirleme kriterlerine ilişkin puanları arasında cinsiyetlerine ve sınıf düzeylerine göre anlamlı bir farkl1lık gösterip göstermediğini belirlemek için iki yönlü Anova testi yapılmıştır. Sonuçlar Tablo 6'da gösterilmektedir.

Tablo 6. Fen Bilgisi Öğretmen Adaylarının Cinsiyet ve Sınıf Düzeylerine Göre Farklı Bilgi Kaynaklarından Alınan Metinlerin, Güvenilirliklerini Belirleme Kriterlerine İlişkin Puanları Arasındaki Farklıı̆̆gn Anlamlılığına İlişkin İki Yönlü Anova Sonuçları

\begin{tabular}{lccccc}
\hline Varyansın Kaynağı & $\begin{array}{c}\text { Kareler } \\
\text { Toplamı }\end{array}$ & sd & $\begin{array}{c}\text { Kareler } \\
\text { Ortalamas1 }\end{array}$ & $\mathrm{F}$ & $\mathrm{p}$ \\
\hline Cinsiyet &, 002 & 1 &, 002 &, 001 &, 979 \\
Sinıf & 15,137 & 3 & 5,046 & 2,056 &, 108 \\
Cinsiyet * Sinıf & 5,223 & 3 & 1,741 &, 709 &, 548 \\
Hata & 436,784 & 178 & 2,454 & & \\
Toplam & 7640,335 & 186 & & & \\
\hline
\end{tabular}

Tablo 6 incelendiğinde, cinsiyetin $(\mathrm{F}=, 001, \mathrm{p}>.05)$ ve sinif düzeyinin $(\mathrm{F}=2,056, \mathrm{p}>.05)$, farklı bilgi kaynaklarından alınan metinlerin, güvenilirliklerini belirleme kriterlerine ilişkin puanları üzerindeki ayrı ayrı etkilerinin ve cinsiyet*sinif ortak etkilerinin $(\mathrm{F}=, 709, \mathrm{p}>.05)$ anlamsız olduğu bulunmuştur. Cinsiyet ve sinıf değişkenleri hem ayrı ayrı hem de birlikte fen bilgisi öğretmen adaylarının farklı bilgi kaynaklarından alınan metinlerin, güvenilirliklerini belirleme kriterlerine ilişkin puanlarını etkilememektedir.

\section{7. "Fen Bilgisi Öğretmen adaylarl, nükleer enerji santralleri konusunda farkl bilgi kaynaklarindan alınan metinlerin kavranmasinı ne ölçüde zor bulmuşlardır?" Alt Problemine İlişkin Bulgular}

Fen Bilgisi Öğretmen adaylarının, nükleer enerji santralleri konusunda farklı bilgi kaynaklarından alınan metinlerin kavranılabilirliğini değerlendirmelerine ilişkin verdikleri puanların dağılımını belirlemek için betimsel istatistik uygulanmıştır. Sonuçlar Tablo 7'de gösterilmektedir.

Tablo 7. Fen Bilgisi Öğretmen Adaylarının Çevrimiçi Bilgi Kaynaklarının Kavranılmasını Değerlendirmelerine İlişkin Betimsel İstatistik Sonuçları*

\begin{tabular}{clcc}
\hline Metin No & Konu/ Kaynak / Yayın Tarihi & $\dot{X}$ & sd \\
\hline 1 & Nükleer Enerji / Röportaj Yazısı/2013 & 3,08 & 1,86 \\
2 & Nükleer Enerji / Dergi Yazısı/2009 & 2,48 & 1,42 \\
3 & Nükleer Enerji / Gazete Haberi/2017 & 2,38 & 1,48 \\
\hline
\end{tabular}




$4 \quad$ Nükleer Enerji / Kitap/2011 2,43 1,46

Toplam

$2,59 \quad 1,25$

*Ölçek, çok kolay (1) ile çok zor (10) arasında derecelendirilmiştir.

Tablo 7’ de, Fen Bilgisi Öğretmen adaylarının nükleer enerji santralleri ile ilgili çevrimiçi farklı bilgi kaynaklarından alınan metinlerin kavranılabilirliğini değerlendirmelerine ilişkin verdikleri puanların ortalamaları ve standart sapma değerleri görülmektedir. Tablo 7 incelendiğinde, fen bilgisi öğretmen adaylarının nükleer enerji santralleri hakkında gazeteden alınmış olan 3.metni (2.38) çok kolay kavranılır bulurken, çevrimiçi röportajdan alınmış olan 1.metni (3.08) daha zor kavranılabilir bulmuşlardır. Ancak, çevrimiçi farklı bilgi kaynaklarından alınan metinlere ilişkin kavranılabilirlik puanları arasında anlamlı bir farklılık bulunmamaktadır.

3.8. "Fen bilgisi öğretmen adaylarının bilgi okuryazarlık becerileri ile çevrimiçi farklı bilgi kaynaklarının güvenilirliklerini değerlendirmeleri arasında anlamlı bir ilişki var mıdır?" Alt Problemine İlişkin Bulgular
Tablo 8'de görüldüğü gibi fen bilgisi öğretmen adaylarının bilgi okuryazarlık becerileri ile çevrimiçi farklı bilgi kaynaklarının güvenilirliklerini değerlendirmeleri arasındaki ilişki düzeyini belirlemek amacıyla korelasyon analizi yapılmıştır. Fen bilgisi öğretmen adaylarının genel olarak sahip oldukları bilgi okuryazarlık beceri düzeyleri ile çevrimiçi farklı bilgi kaynaklarının güvenilirliklerini değerlendirmeleri arasında düşük düzeyde ve pozitif yönde ( $\mathrm{r}=.093$ ) bir ilişkinin olduğu belirlenmiştir. Bu bulguya göre, öğretmen adaylarının bilgi okuryazarlık beceri düzeyleri arttıkça buna paralel olarak çevrimiçi farklı bilgi kaynaklarının güvenilirliklerini değerlendirme becerilerinin de düşük düzeyde bir artış gösterdiği söylenebilir. Bilgi okuryazarlığı ölçeğinin alt boyutları ile bilgi kaynaklarının güvenilirliğini değerlendirme ölçeğinin alt boyutları arasındaki ilişkinin düzeyini belirleyen korelasyon değerlerinin ise $r=.-335$ ile $r=.279$ arasında değiştiği görülmektedir. $\mathrm{Bu}$ iki değer arasındaki tüm değerler de değişkenler arasındaki ilişkinin düşük düzeyde olduğunu göstermektedir.

Tablo 8. Fen bilgisi öğretmen adaylarının bilgi okuryazarlık becerileri ile çevrimiçi farklı bilgi kaynaklarının güvenilirliklerini değerlendirmeleri arasındaki ilişki düzeyine ilişkin Sonuçlar*

\begin{tabular}{|c|c|c|c|c|c|c|c|c|c|}
\hline \multirow{2}{*}{ Bilgi Okuryazarlığı / Alt Boyutları } & \multirow{2}{*}{ 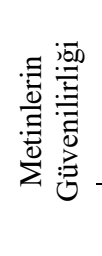 } & \multicolumn{6}{|c|}{ Güvenilirlik Kriterleri } & \multirow{2}{*}{ 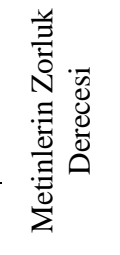 } & \multirow{2}{*}{ 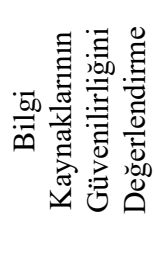 } \\
\hline & & Yazarı & Yayıncis1 & Türü & İçeriği & Kendi Görüşü & $\begin{array}{l}\text { Yayın } \\
\text { Tarihi }\end{array}$ & & \\
\hline$\overline{\text { Bilgi Okuryazarlığı (Genel) }}$ & & & & & & & & & .093 \\
\hline BİT & & & &, $177 *$ & & & & $-.335 * *$ & \\
\hline $\mathrm{BE}$ &, $189 * *$ & &, $174^{*}$ &, $193 * *$ & &, $174 *$ &, $197 * *$ & $-.265^{* *}$ & \\
\hline $\mathrm{BK}$ & & & & & & & & $-.251 * *$ & \\
\hline BKEYD & &, $175^{*}$ &, $245^{* *}$ &, $279 * *$ & & &, $257 * *$ & & \\
\hline
\end{tabular}

*Tabloda yer alan kısaltmalar: Bilgi İhtiyacını Tanımlama (BİT), Bilgiye Erişme (BE), Bilgiyi Kullanma (BK), Bilgiyi Kullanmada Etik ve Yasal Düzenlemeleri Dikkate Alma (BKEYD)

\section{Tartışma ve Sonuç}

Fen bilgisi öğretmen adaylarının bilgi okuryazarlık becerileri ile çevrimiçi farklı bilgi kaynaklarından alınan metinlerin güvenilirliklerini nasıl değerlendirdiklerinin incelendiği bu çalışmada elde edilen bulgulara dayalı olarak aşağıdaki sonuçlara ulaşılmıştır.

Fen bilgisi öğretmen adaylarının, bilgi okuryazarlığı konusunda yüksek beceri düzeyine sahip oldukları sonucu elde edilmiştir. Çalışmada ulaşılan bu sonucu, bilgi okuryazarlık beceri düzeylerinin üst düzeyde bulunduğu (Adıgüzel, 2014; Argon, Öztürk ve Kilıçaslan, 2008; Demiralay ve Karadeniz, 2010; Dombaycı ve Ercan, 2017; Korkut ve Akkoyunlu, 2008; Özbay ve Çelik, 2013) birçok araştırmanın sonucu destekler niteliktedir. Buna karşın, Ünal ve $\operatorname{Er}(2015)$ in, sosyal bilgiler öğretmen adaylarının yeterli bilgi okuryazarlık düzeyine sahip olmadıklarını belirlediği araştırmanın sonucu ise desteklememektedir. Pek çok araştırmada bilgi okuryazarlığını etkileyen farklı değişkenlerden söz edilmektedir (Adıgüzel, 2014; Argon vd., 2008). Örneğin; Adıgüzel (2014) kendini tanıyan öğrencilerin, araştırma amacıyla interneti kullanan öğrencilerin ve başarılı öğrencilerin bilgi okuryazarlıklarını daha yüksek bulmuştur. Buradan hareketle farklı gruplarla yapılan çalışmalardaki kişilerin genel özelliklerinin de farklılık gösterebileceği göz önünde bulundurularak Ünal ve Er' in (2015) çalışmasıyla sonuçların paralellik göstermediği düşünülmektedir.

Fen bilgisi öğretmen adaylarının bilgi okuryazarlık puanlarının cinsiyetlerine ve sınıf düzeylerine göre anlamlı bir farklılık göstermediği sonucuna ulaşılmıştır. Dombaycı ve Ercan (2017) kadın öğretmen adaylarının bilimsel okuryazarlık puanlarının, erkek öğretmen adaylarından anlamlı derecede yüksek olduğu sonucuna ulaşırken, Argon vd. (2008) k1z ve erkeklerin bilgi okuryazarlık puanları arasında farklılık olmamasına rağmen farklı kaynaklara ulaşma gibi madde bazında cinsiyetler arasında farklılıkların olduğunu tespit etmişlerdir. Öte yandan, bilgi okuryazarlık puanlarının cinsiyete göre (Adıgüzel, 2014; Korkut ve Akkoyunlu, 2008; Tekin, Aslan ve Yağız, 2016; Ünal ve Er, 2015) ve sınıf düzeyine göre farklılaşmadığının (Korkut ve Akkoyunlu, 2008; Argon vd., 2008; Ünal ve Er, 2015) tespit edildiği birçok araştırmanın sonucu ise bu araştırmada elde edilen sonucu destekler niteliktedir. $\mathrm{Bu}$ çalışmanın veya 
yapılan diğer çalışmaların birbirleriyle farklılık göstermesinin bireysel farklılıklardan kaynaklandığı düşünülmektedir.

Elde edilen diğer bir sonuç, fen bilgisi öğretmen adaylarının çevrimiçi farklı bilgi kaynakları arasında dergiden alınmış olan metni daha az güvenilir bulurken, kitaptan alınmış olan metni daha güvenilir buldukları ve farklı bilgi kaynaklarından alınan metinlerin güvenilirliklerini değerlendirmelerine ilişkin puanları arasında cinsiyetlerine ve sınıf düzeylerine göre anlamlı bir farklılık olmadığıdır. Daha az güvenilir buldukları çevrimiçi dergiden alınmış olan metnin içeriğine bakıldığında nükleer enerji santralinin ülkemiz için gerekliliği ve Çernobil gibi kötü bir örneğin emsal teşkil etmemesi gerektiğinin savunulduğu, daha güvenilir buldukları çevrimiçi kitabın içeriğinde ise nükleer enerji santrallerinin kurulmasının olumsuz sonuçlarının yer aldığ 1 görülmektedir. Fen bilgisi öğretmen adaylarının nükleer enerji santrallerinin kurulmasına ilişkin olumsuz tutum (Sürmeli, Duru ve Duru, 2017) ve görüşe sahip oldukları (Ateş ve Saraçoğlu, 2013) yönünde sonuçların elde edilmiş olduğu araştırma sonuçları da çalışmanın sonuçlarını destekler niteliktedir. Sürmeli vd. (2017) araştırmalarında öğretmenlerin nükleer enerji kullanımı ve nükleer enerji santrallerinin kurulmasına karşı tutumları arasında cinsiyet açısından, Özdemir ve Çobanoğlu (2008) da cinsiyet ve sınıfa göre farklılıklar olduğunu tespit etmişlerdir. Nükleer enerjiye yönelik tutumların, nükleer politikayı belirleyen kurumlara ilişkin algının bir fonksiyonu olduğunu düşünen ve bu düşünceden hareketle 18 yaş ve üstü 380 yetişkinle araştırmalarını yürüten Whitfield, Rosa, Dan ve Dietz (2009) ise nükleer tutumun cinsiyet, yaş, eğitim, gelir veya siyasi yönelim gibi değişkenlere göre farklılaşmadığı yönünde sonuç elde etmişlerdir. Whitfield vd. (2009) elde ettikleri sonuç da mevcut çalışmayı desteklemektedir. Bu durum, öğretmen adaylarının nükleer enerji santrallerinin kurulmasına ilişkin cinsiyet ve sınıf fark etmeksizin olumsuz düşünceye sahip olmalarının çevrimiçi bilgi kaynaklarının güvenilirliğini belirlemelerinde güvenilirlik kriterlerinden öte nükleer enerji santrallerine yönelik tutumlarının etkili olduğunu düşündürmektedir.

Fen bilgisi öğretmen adaylarının, metinlerin güvenilirlikleri hakkındaki kararlarını en çok metnin içeriği ve kendi görüşleri doğrultusunda verdikleri, metinlerin yayıncılarını ve metinlerin türünü ise güvenilirlik hakkında karar vermede en az dikkate aldıkları, metinlerin güvenilirliklerini belirleme kriterlerine ilişkin puanları arasında cinsiyetlerine ve sınıf düzeylerine göre anlamlı bir farklılık olmadığı da bulgulardan hareketle elde edilen bir başka sonuçtur. Geçer (2014) de araştırmasında öğrencilerin web ortamında bilgi arama ve yorumlama stratejilerinde cinsiyete göre anlaml bir farklılık olmadığı yönünde sonuç elde ederken, Liang ve Tsai (2009) ise cinsiyete göre farklılığın anlamlı olduğu sonucuna ulaşmıştır. Cinsiyet ve sınıf düzeyi ile çevrimiçi bilgi kaynaklarının güvenilirliğine ilişkin karar verme kriterleri arasındaki ilișkiyi araştıran çalıșmaların yapılması sonuçların genellenebilirliğini arttırabilir. Fen bilgisi öğretmen adaylarının güvenilirlik hakkındaki kararlarını en çok kendi fikirleri ve içeriğine bakarak verdikleri yönündeki literatür de (Bråten, Strømsø ve Britt, 2009; Bråten vd., 2011; Saylan, 2014) sonucu destekler niteliktedir. Elde edilen bu sonuç, öğretmen adaylarının çevrimiçi farklı bilgi kaynaklarından alınan metinlerin güvenilirliğini belirlemede, metinlerin içerikleri ve kendi düşünceleri gibi sınırlı sayıda kriteri dikkate aldıklarını, metinlerin güncelliği, yazarı, türü ve yayın organı gibi birçok kriteri ise en az dikkate aldıklarını göstermektedir. Aldemir (2004) de öğretmen adaylarının web kaynaklarını güncellik, güvenirlik, doğruluk ve tarafsızlık gibi unsurlar açısından değerlendirme konusunda kararsızlık yaşadıklarını tespit etmiştir. Oysaki içinde bulunduğumuz yüzyıl, eleştirel düșünebilen, sorgulayan, bilinçli kararlar verebilen, dijital ve bilgi okuryazarı bireylerin yüzyılıdır ve bu niteliklere sahip bireylerin yetişebilmesi için öğretmen adaylarının da bu özelliklere sahip olarak yetişebilmeleri büyük bir önem arz etmektedir; ancak elde edilen sonuç, öğretmen adaylarının söz konusu nitelikler açısından eksikliklerinin olduğunu, etkili uygulamalarla yetiştirilmeleri sürecinde iyileştirmelerin gerekliliğini ortaya çıkarmıştır.

Fen bilgisi öğretmen adayları, gazeteden alınmış olan metni daha kolay kavranılır, çevrimiçi röportajdan alınmış olan metni ise daha zor kavranılabilir bulduklarını belirtmişlerdir. Haber metinlerinin ve röportaj metinlerinin ortak yanları her ikisinin de haber yazısı olmaları ve bilgilendirme amaçlı olmalarıdır; ancak haber metinlerinde haberin veriliş şekli objektif ancak röportaj da ise subjektiftir yani röportajda yazarın kişisel görüşleri yer alır. Mevcut araştırmada gazeteden alınan metin nükleer enerji santrallerine yönelik olumsuz bilgiler içermekte, metinler arasında sadece röportaj metinde ise röportaj yapılan kişinin nükleer enerji santrallerinin gerekliliğine ilişkin görüşleri yer almaktadır. $\mathrm{Bu}$ durum, nükleer enerji santrallerine yönelik olumsuz tutumlarının etkisinde kaldıklarını düşündürmektedir.

Araştırmada ayrıca, fen bilgisi öğretmen adaylarının bilgi okuryazarlık beceri düzeyleri ile çevrimiçi farklı bilgi kaynaklarının güvenilirliklerini değerlendirmeleri arasında düşük düzeyde ve pozitif yönde bir ilişkinin olduğu belirlenmiştir. Akkoyunlu ve Yılmaz (2005) da araştırmalarında öğretmen adaylarının bilgi okuryazarlık düzeyleri arttıkça internet kullanım sıklıklarının arttığı ve öğretmen adaylarının interneti genellikle bilgiye ulaşma amaçlı kullandıkları yönünde bir sonuç elde etmişlerdir. Bilgi okuryazarlı beceri düzeylerinin artmas1, web ortamında bilgi arama ve bilginin doğruluğunu, güncelliğini, doğruluğunu ve güvenilirliğini değerlendirme becerilerini arttırmada önemli bir faktör olduğu söylenebilir.

\section{5. Öneriler}

Araştırma sonucunda elde edilen bulgulardan yola çıkılarak öğretmen adaylarının bilgi okuryazarlığ 1 ve çevrimiçi farklı bilgi kaynaklarından alınan metinlerin güvenilirliklerini değerlendirme kriterlerini geliştirmeye yönelik çeşitli önerilerde bulunulabilir. Söz konusu öneriler şu şekilde siralanabilir:

Öğretmen adaylarının bilgi okuryazarlığı konusunda yüksek beceri düzeyine sahip olmalarına rağmen nükleer enerji santrallerinin kurulmasına ilişkin cinsiyet ve sınıf fark etmeksizin olumsuz düşünceye sahip oldukları ve çevrimiçi bilgi kaynaklarının güvenilirliğini belirlemelerinde güvenilirlik kriterlerinden öte nükleer enerji santrallerine yönelik tutumlarının etkili olduğu sonucuna ulaşılmıştır. Çevrimiçi bilgi kaynaklarını değerlendirme sürecine ilişkin farkındalıklarının arttırılması için son yıllarda çokça gündemde olan nükleer enerji, GDO, kök hücre ve 
nanoteknoloji gibi sosyobilimsel konuların ele alındığı bilgi arama ve yorumlama stratejileri seminerleri düzenlenebilir.

Öğretmen adaylarının çevrimiçi farklı bilgi kaynaklarından alınan metinlerin güvenilirliğini belirlemede, metinlerin içerikleri ve kendi düşünceleri gibi sınırlı sayıda kriteri dikkate aldıkları, metinlerin güncelliği, yazarı, türü ve yayın organı gibi birçok kriteri ise en az dikkate aldıkları yönünde sonuç elde edilmiştir. Oysaki içinde bulunduğumuz yüzyıl, eleştirel düşünebilen, sorgulayan, bilinçli kararlar verebilen, dijital ve bilgi okuryazarı bireylerin yüzyılıdır ve bu niteliklere sahip bireylerin yetişebilmesi için öğretmen adaylarının da bu özelliklere sahip olarak yetişebilmeleri büyük bir önem arz etmektedir. Söz konusu nitelikler açısından öğretmen adaylarının daha iyi yetiştirilebilmeleri için eğitim fakültelerinin programlarında 'Araştırmalar için Çevrimiçi Bilgi Kaynaklarının Kullanımı’ dersi açılarak, bu derslerde çevrimiçi bilgi kaynaklarının tanınması, bilgiye erişim, bilgiyi kullanma ve bilgiyi değerlendirme konuları ele alınabilir.

Bilginin giderek artan bir şekilde çevrimiçi olarak günlük hayata girdiği bu çağda, maruz kalınan her türlü kaynağın güvenirliğini değerlendirmek adına sadece lisans düzeyinde değil temel eğitim düzeyinden başlayarak farklı derslerin programlarında bilgi okuryazarlığını geliştirici etkinliklere yer verilebilir. Sosyobilimsel konular içeren fen bilimleri dersi bu etkinlikler için uygun bir içerik sunabilir.

Araştırmacılara, eğitim fakültelerinin müfredatında yer alan derslerin içeriklerinin, öğretmen adaylarının bilgi okuryazarlığı becerilerini geliştirmeye ve çevrimiçi bilgi kaynaklarının güvenilirliğini değerlendirmeye yönelik olup olmadığını, derinlemesine bilgi elde edebilecekleri nitel yaklaşımlarla destekleyerek araştırmaları önerilebilir.

İlkokuldan başlayarak tüm öğrencilerin internetten yoğun bir şekilde yararlandıkları düşünüldüğünde, bu araştırmanın ilk ve ortaöğretimde öğrenim görmekte olan öğrencilerle de yapılması, daha erken yaşlardan itibaren bilgi okuryazarlığı ve çevrimiçi bilgi kaynaklarının güvenilirliğini değerlendirmelerine ilişkin yaklaşımlarının belirlenmesine yardım edebilir.

\section{Kaynakça}

ACRL (2000). Information literacy competency standarts for higher education. (Erişim: 02.01.2018), http://www.ala.org/acrl/ilstandartlo.htm

Adıgüzel, A. (2011). Bilgi okuryazarlığı ölçeğinin geliştirilmesi. Dicle Üniversitesi Ziya Gökalp Ĕ̆itim Fakültesi Dergisi, 17, 15-28.

Adıgüzel, A. (2014). Öğretmen adaylarının öğrenmeye ilişkin tutumları ile bilgi okuryazarlık becerileri arasındaki ilişkinin çeşitli değişkenler açısından incelenmesi. Uluslararası Eğitim Programlarl ve Öğretim Çalışmaları Dergisi, 4(7), 13-24.

Akkoyunlu, B., \& Yılmaz, M. (2005). Öğretmen adaylarının bilgi okuryazarlık düzeyleri ile internet kullanım sıklıkları ve internet kullanım amaçları. Ĕğitim Araştırmaları, 19, 1-14.

Akolaş, A. (2004). Bilişim sistemleri ve bilişim teknolojisinin küreselleşme olgusu ve girişimcilik üzerine yansımaları. Selçuk Üniversitesi Sosyal Bilimler Enstitüsü Dergisi, 12, 29-43.

Aldemir, A. (2004). Öğretmen adaylarının bilgi okuryazarlı̆̆ düzeyleri üzerine bir araştırma: Sakarya üniversitesi örneği. Yüksek Lisans Tezi. Ankara: Hacettepe Üniversitesi.

Alexandria Proclamation (2005). Alexandria proclamation on information literacy and lifelong learning: Beacons of the information society. (Erişim: 10/01/2018), https://www.ifla.org/publications/beacons-of-theinformation-society-the-alexandria-proclamation-oninformation-literacy

Argon, T., Öztürk, Ç., \& Kılıçaslan, H. (2008). Sınıf öğretmenliği öğretmen adaylarının bilgi okur-yazarlığ becerileri üzerine bir durum çalışması. Abant İzzet Baysal Üniversitesi Eğitim Fakültesi Dergisi, 8(2), 13-22.

Ateş, H., \& Saraçoğlu, M. (2013). Fen bilgisi öğretmen adaylarının gözünden nükleer enerji. Ahi Evran Üniversitesi Kırşehir Eğitim Fakültesi Dergisi, 14(3), 175-193.

Bedük, A. T., \& Balcılar, H. T. (2008). Türkiye'nin bilgi toplumu olma yolunda bilgi teknolojilerinden internetin kullanımı: Muş ilindeki internet kafe kullanıcılarının amaçları üzerinde bir araştırma. Selçuk Üniversitesi Iktisadi ve İdari Bilimler Fakültesi Sosyal ve Ekonomik Araştırmalar Dergisi, 9(16), 83-106.

Bozkurt, A. (2014). A $\breve{g}$ toplumu ve bilgi. Türk Kütüphaneciliği, 28(4), 510-525.

Bråten, I., Strømsø, H. I., \& Britt, M. A. (2009). Trust matters: examining the role of source evaluation in students' construction of meaning within and across multiple texts. Reading Research Quarterly, 44, 6-28.

Bråten, I., Strømsø, H. I., \& Salmerón, L. (2011). Trust and mistrust when students read multiple information sources about climate change. Learning and Instruction, 21, 180192.

Değirmencioğlu, G. (2016). Dijitalleşme çağında gazeteciliğin geleceği ve inovasyon haberciliği. TRT Akademi, 1 (2), 590-606.

Demir, Ö., \& Seferoğlu, S.S. (2016). Bilgi okuryazarlığı, internet bağımlılığı, sanal aylaklık ve çeşitli diğer değişkenlerin sanal zorbalık ile ilişkisinin incelenmesi. Online Journal of Technology Addiction \& Cyberbullying, 3(1), 1-26.

Demiralay, R., \& Karadeniz, Ş. (2010). Bilgi ve iletişim teknolojileri kullanımının, ilköğretim öğretmen adaylarının bilgi okuryazarlığı öz-yeterlik algılarına etkisi. Kuram ve Uygulamada Eğitim Bilimleri, 10(2), 819-851.

Dobrow, S. B. (2013). Rise of the Internet and the World Wide Web. Salem Press Encyclopedia. (Erişim: 10/01/2018),

http://eds.a.ebscohost.com/eds/detail/detail? vid=5\&sid= 77cf002f-a29b-447e-9b19-

10275 dfed690\%40sessionmgr4010\&bdata=Jmxhbmc9d $\mathrm{HI} \% 3 \mathrm{~d} \# \mathrm{AN}=89315939 \& \mathrm{db}=\mathrm{ers}$ 
Dombaycı, M. A., \& Ercan, O. (2017). Öğretmen adaylarının bilimsel okuryazarlık düzeyleri ve bilimsel araştırmaya yönelik tutumlarının çeşitli değişkenler açısından incelenmesi. Abant İzet Baysal Üniversitesi Ĕ̈itim Fakültesi Dergisi, 17 (3), 1265-1284.

Geçer, A. (2014). Öğretmen adaylarının web ortamında bilgi arama-yorumlama stratejilerinin demografik değişkenlere göre incelenmesi. Ĕ̆itim Teknolojisi Kuram ve Uygulama, 4(2), 1-20.

Horton, F. W. (2008). Understanding information literacy: A primer. (Erişim: 10/01/2018), http://akgul.bilkent.edu.tr/IFAP/UnderstandingInformation-Literacy-A-Primer.pdf

Karasar, N. (2014). Bilimsel araştırma yöntemi. Ankara: Nobel Yayınevi.

Kılıç, S. (2013). Örnekleme yöntemleri. Journal of Mood Disorders, 3(1), 44-50.

Kolstø, S. D. (2001). Scientific literacy for citizenship: tools for dealing with the science dimension of controversial socioscientific issues. Sci. Ed., 85, 291-310. http://dx.doi.org/10.1002/sce.1011

Korkut, E., \& Akkoyunlu, B. (2008). Yabancı dil öğretmen adaylarının bilgi ve bilgisayar okuryazarlık özyeterlilikleri. Hacettepe Üniversitesi Eğitim Fakültesi Dergisi, 34, 178-188.

Lemke, C., \& Brenner, W. (2015). Einführung in die wirtschaftsinformatik, band 1: verstehen des digitalen zeitalters, 11-51. Berlin, Heidelberg: Springer Verlag. (Erişim: 29/12/2017) http://www.springer.com/cda/content/document/cda_do wnloaddocument/9783662440643-c1.pdf?SGWID=0-045-1486970-p176975505

Liang, J. C., \& Tsai, C. C. (2009). The information commitments toward web information among medical students in Taiwan. Educational Technology and Society, 12(1), 162-172.

Murugesan, S. (2014). Succeeding as an IT Professional. IT Professional, 16(1), 2-4. http://dx.doi.org/10.1109/MITP.2013.103

Özbay, M., \& Çelik, M. E. (2013). Türkçe öğretmeni adaylarının bilgi okuryazarlık düzeylerinin incelenmesi. Ana Dili Ĕgitimi Dergisi, 1(4), 10-21.

Özdemir, N., \& Çobanoğlu, E. O. (2008). Türkiye'de nükleer santrallerin kurulması ve nükleer enerji kullanımı konusundaki öğretmen adaylarının tutumları. Hacettepe Üniversitesi Ĕ̆itim Fakültesi Dergisi, 34, 218-232.

Sayers, R. (2006). Principles of awareness-raising for information literacy: a case study. UNESCO Bangkok. (Erişim: 13.01.2018) http://unesdoc.unesco.org/images/0014/001476/147637e .pdf

Saylan, A. (2014). Fen bilgisi ögretmen adaylarının epistemolojik inançlarl; iklim değişikliği, nükleer enerji ve organ bağışı ve nakli hakkındaki bilgi düzeyleri ile bilgi kaynaklarına olan güvenleri arasındaki ilişkiler. Doktora Tezi. Ankara: Ortadoğu Teknik Üniversitesi.
Sürmeli, H., Duru, N., \& Duru, R. (2017). Investigating teachers' attitudes towards nuclear energy and nuclear power plants in terms of different variables. Necatibey Eğitim Fakültesi Elektronik Fen ve Matematik Eğitimi Dergisi, $11 \quad$ (1), 293-319. http://dx.doi.org/10.17522/balikesirnef.356156

Tekin, N., Aslan, O., \& Yağız, D. (2016). Fen bilimleri öğretmen adaylarının bilimsel okuryazarlık düzeyleri ve eleştirel düşünme eğilimlerinin incelenmesi. Amasya Üniversitesi Eğitim Fakültesi Dergisi, 5(1), 23-50. http://dx.doi.org/10.17539/aej.76710

Ünal, F., \& Er, H. (2015). Sosyal bilgiler öğretmen adaylarının bilgi okuryazarlığı düzeylerinin değerlendirilmesi, Journal of International Social Research, 8(41), 1059-1068.

Van den Bosch, A., Bogers, T., \& De Kunder, M. (2016). Estimating search engine index size variability: a 9-year longitudinal study. Scientometrics, 16(2), 1-20. http://dx.doi.org/10.1007/s11192-016-1863-z

Whitfield, S. C., Rosa, E. A., Dan, A., \& Dietz, T. (2009). The future of nuclear power: value orientations and risk perception. Risk Analysis: An International Journal, 29(3), 425-437. http://dx.doi.org/10.1111/j.15396924.2008.01155.x

Yörükoğulları, E., Orhun, Ö., Topdemir, H. G., \& İhsanoğlu, E. (2013). Bilim ve teknoloji tarihi. Eskişehir: Anadolu Üniversitesi Yayını. 